\title{
Empress Influence on the Establishment and Rise in Popularity of the Virgin Mary and Kuan Yin
}

\author{
Krista K. Rodin \\ Northern Arizona University, Flagstaff, Arizona, USA
}

\begin{abstract}
The feminine spiritual figures of compassion, the Catholic Christian Virgin Mother Mary, and the Chinese Buddhist, Kuan Yin, share a number of traits and attributes in spite of their cultural differences. They also share a common history in the development of their devotional worship through two empresses who identified themselves with their respective cultural icon thereby enhancing their political roles while endearing themselves to the common people through their promotion of the spiritual figures of compassion. This paper seeks to show the parallels between the rise in devotion to the Virgin Mary under the Byzantine Empress Pulcheria (399-453) and the corresponding rise in the interest in, and feminization of, Avalokiteshvara/Kuan Yin under the Tang Dynasty Empress Wu Zetian (625-705). While there has been a substantial amount written about how ancient political leaders used selected deities as vehicles for asserting their power, there are only a few that have looked at these two unique Empresses and none that compares their influence in the popularization of devotional worship to Mary and Kuan Yin. This study attempts to begin to fill that gap.
\end{abstract}

Keywords: Pulcheria, Wu Zetian, Virgin Mary, Kuan Yin, Tang Dynasty, Byzantine Empire

\section{Introduction}

The feminine spiritual figures of compassion, the Catholic Christian Virgin Mother Mary, and the Chinese Buddhist, Kuan Yin, share a number of traits and attributes in spite of their cultural differences. They also share a common history in the development of their devotional worship through two empresses who identified themselves with their respective cultural icon thereby enhancing their political roles while endearing themselves to the common people through their promotion of the spiritual figures of compassion. They diverge, however, in their legacies due in part to the influence, or lack of it, of religious institutional support. This paper seeks to show the parallels between the rise in devotion to Mary under the Byzantine Empress Pulcheria (399-453) and the corresponding rise in the interest in Avalokiteshvara/Kuan Yin under the Tang Dynasty Empress Wu Zetian (625-705) and how these two religiously powerful women rulers have vastly different legacies. While there has been a substantial amount written about how ancient political leaders used specially selected deities as vehicles for asserting their power, there are only a few that have looked at the these two unique empresses' promotion and use of their figures of worship. None of them, however, has compared the influence these Empresses had in promoting devotion to a sacred female figure in a male dominated religion. This paper contends that the rise in the popularization of the cults of the Virgin Mary and that of Kuan Yin was at least in part based on the efforts of their culture's respective Empress. Both Empress Pulcheria and Empress

Krista K. Rodin, Ph.D., Professor of Humanities, Northern Arizona University. 
Wu Zetian identified themselves with the spiritual figure and supported the construction of churches and pagodas for their worship across their wide-ranging Empires while fostering the creation and distribution of sacred texts that supported their religious beliefs.

The paper is organized into three sections: Empress Pulcheria, Empress Wu Zetian, and Common Threads. The first is an introduction to Empress Pulcheria and her relationship with Mary, the second an introduction to Empress Wu's support of Buddhism in the early Tang Dynasty which led to the feminization of the Bodhisattva, Kuan Yin, and finally some common threads of the Empresses' use of imperial power to promote their religious causes, foster devotional relationships to their chosen figures, while using the sacred images to solidify their political roles and as a basis for philanthropic endeavors.

\section{Empress Pulcheria}

Empress Pulcheria (399-453) came from a Spanish-Frankish family and her Western Roman Empire heritage came through in her unabated support of the Roman Pope over more Eastern Church fathers. Pulcheria was the oldest daughter of Emperor Arcadius, and granddaughter of Theodosius I, who made Christianity the state religion of the Roman Empire in 389. When her father died in 408, her younger brother, Theodosius II, assumed the throne when he was only seven. Their mother, Eudoxia, had died a few years earlier, in 404. By 414, the Senate had proclaimed Pulcheria "Augusta” (empress) and made her regent for her younger brother. During their childhood, the family's spiritual director and tutor was Atticus, who developed a "Treatise on Faith and Virginity” for Pulcheria and her younger sisters. While the work has disappeared, Constas cites Kenneth Holum's argument that it probably "Exalted women and presented the Mother of God as the archetypal virgin whose chastity the three sisters would do well to emulate. If they did, Atticus suggested, Christ would be born in them mystically, just as he had taken form in the womb of Mary.” He also added a Marian feast to the Church calendar (Constas, 1995, p. 172). Atticus' influence can be seen that on the day of her investiture she went from the civil ceremony to the Basilica of St. Sophia to take her spiritual vows (Teetgan, 2010, p. 84). From the time she was named Empress, Pulcheria vowed to remain a virgin and convinced her younger sisters to do the same. The vow was taken at the altar of the Great Church of St. Sophia; her image was placed above the altar and her robe, possibly personally woven, placed on the altar. Her vow was etched onto the table itself. There is some question as to whether this vow was taken, by age 15, out of an inner conviction to be married to Christ and her devotion to the Virgin Mary or whether she was aware, even at that young age, that marriage would undermine her political influence. Whatever her reasons, she stayed true to her vow throughout her life. Her vow and the placing of her image above the altar are among the first documented events of how Pulcheria merged emotionally and spiritually with the Virgin Mary and how that would influence her political affairs.

Brother and sister co-ruled for the next ten years, prior to his marriage, arranged by Pulcheria, to the Greek Princess Eudocia. Throughout this early time it appears that Pulcheria was the stronger and more influential of the two sibling rulers as Theodosius appears to have been swayed by whoever had his ear at a given moment. After Theodosius' marriage, Pulcheria left the court and retired to a cloister away from the hub of political activity, but still within Constantinople, to meditate and fulfill her desire to be a nun. It seems that the two empresses, Pulcheria, who remained Empress while a nun, and Eudocia, got along in the beginning, but as Eudocia tried to exert her influence over her husband, Pulcheria felt she was being pushed aside. This didn't seem to bother her until Eudocia reached into the spiritual affairs of the Empire by influencing the Emperor to 
appoint Nestorius as the Archbishop of Constantinople in 428. Nestorius came to the capital from Antioch, where there was a distinct separation of the sexes during worship and little regard for the figure of Mary in Church theology. He was "scandalized by the devotion to the Virgin which he encountered upon his arrival in Constantinople." According to legend, he went so far as to prohibit Pulcheria from taking communion at the altar as, according to his training and tradition, that was reserved for priests. She asked "Why? Have I not given birth to God?" "You?” he retorted, "Have given birth to Satan," and proceeded to drive Pulcheria from the sanctuary" (Constas, 1995, p. 174). This was a call for battle; "Pulcheria understood attacks on the Theotokos as a personal affront ... (she) had taken the Virgin Theotokos as the model of her life.” According to Limberis "When she claimed that her identity was the Virgin's suddenly the identity of the Theotokos was merged with the imperial power Pulcheria held as Augusta” (Atanassova, 2010, p. 141). To make matters worse, Nestorius removed Pulcheria's image from the Church and refused to "use her robe as an altar cover" as had been the previous practice (Teetgen, 2007, p. 3).

This affront to the Virgin as well as to Pulcheria's personal imperial power could not go unchallenged. When Nestorius didn't back down, but rather started to publically denounce the dignity, reverence, and term “Theotokos”, Mother of God, for the Virgin Mary, the factions threatened to tear apart the young Church. In order to ease the tensions in the Church, Pulcheria and the Emperor called for the Third Ecumenical Council in Ephesus in 431, to decide on the official Church doctrine of the nature of Christ. Nestorius believed that Christ was born a man who had divinity within him, and that there were essentially two natures in Christ; therefore, the appropriate title for the Mother of Jesus, should be Christokos, not Theotokos. Pulcheria, meanwhile, had found a personal and Marian supporter in St. Cyril of Alexandria, a natural theological opponent of Nestorius. St. Cyril's argument and support of the Theotokos, won the day and Nestorius was banned as a heretic. When the Council announced its verdict, the people acclaimed the victory of Mary the Theotokos and Pulcheria as Mary's advocate: "Mary the Virgin has deposed Nestorius! Many years to Pulcheria! She is the one who has strengthened the faith!” (Atanassova, 2010, p. 142).

The debate on nature of Christ, and hence the nature of Mary, did not die after the Council of Ephesus, however. It was again the main topic of the Fourth Ecumenical Council in 451 in Chalcedon, and once more, Pulcheria had an influential role. Life had changed dramatically for her in 450 when Theodosius II fell from his horse and shortly thereafter died. Pulcheria was made sole empress, but recognizing that a woman alone on the throne would be under constant threat, she agreed to marry General Marcian on the understanding that she maintained her virginity. Marcian agreed, she proclaimed him "Augustus," and the two co-ruled the Eastern Empire until her death in 453. In the meantime, however, the debate on the nature of Christ had not abated. In 449 there was a Second Council in Ephesus, which supported Eutyches, an outspoken head of a local monastery, who asserted that the combined human and divine natures of Christ became One with the incarnation. While this was in line with Alexandrian doctrine, he was politically pressed into a theological contest with Flavian, Bishop of Constantinople, on the extent to which Christ was fully human. In 451 the Emperors Pulcheria and Marcian called for another Council, this time in Chalcedon to finally settle the issue. Pulcheria was in touch with Proclus, a local priest who was a staunch supporter of the Virgin Mary and who was renowned as a popular preacher, and Pope Leo in Rome, who actually came to Constantinople for the sixth session to lend his support to the Empress' position. Proclus was instrumental in the development of the idea of the single incarnation, or hypostasis, in Christ. The outcome of this Council was the concept of the Trinitarian God, in which the Father, Son and Holy Spirit are of one essence; they are a "mystical union". This reaffirms 
the place for the Theotokos in the theology of the Church, by making her the second Eve, the one whose obedience to God paves the way for salvation through her divine son. He is the one who portrays her with vibrant images as "a harbor, a sea, a ship, a wall, a bridge, a city, a palace, a throne, a festival, a workshop" among other epitaphs, including "the earth" (Constas, 1995, p. 180).

In the twenty years between the two Councils, Pulcheria was an active Empress, building three churches in the city to honor the Virgin Mother and providing support for the poor in Constantinople. In other parts of the Empire she authorized more churches, hospitals, and houses for pilgrims all of which contributed to her popularity with the citizenry and with the Western Church fathers. It was also supported by her distributed philanthropy. She promoted "Steps", local distribution sites for grain, bread, and foodstuffs that were built upon a pedestal surrounded by four sets of steps. Anyone with a ticket, or its equivalent, could retrieve as much as they were allotted. She also maintained a system of health care providers whose services were free to local populations. Local parishes supported the poor and could ask for the Empress' assistance, especially in plague-stricken areas. She supported all these efforts in part through her own wealth, which she completely gave away to the poor. Through these efforts she was able to gain support not only for her personal causes, but the construction kept people employed and actively contributing to the emerging theocracy of the early Byzantine Empire. The Church, and especially, the worship of the Virgin, allowed former pagan worshippers, whose temples to Artemis, Athena, Aphrodite, Cybil, Hera etc. dotted the Asia Minor landscape to easily transfer their loyalty to the figure of the sacred feminine in the new churches. These acts of compassion demonstrated her connection with her spiritual patron, the Virgin Mary, as well as broadened her influence and respect among the common people.

Pulcheria did not attend the Church Councils, but her influence was distinctly felt in the deliberations of the various factions at those synods. She used sacred texts and images to further her position politically as well as in support of her devotion to the Virgin Mother Mary. It was said, "She governed the Roman world most ably, but referred everything praiseworthy to her brother" (Teetgan, 2010, p. 3). She used the holy figure as a rallying cry in a war against the unbelieving Persians and won. In 422 the Persian king killed a Christian bishop who had desecrated a Zoroastrian altar and Pulcheria convinced Theodosius to avenge the bishop's death. The Emperor credited the victory to his sister's virginity and her identification with the Virgin. This emotional bond with the Virgin also led to the construction of churches dedicated to the Mother of God and to the establishment of the cult of Mary through relics, such as the Virgin's girdle that Pulcheria brought from the Levant to the capital city as well as St. Luke's Hodgeteria, the earliest known image of Mary with the infant on her lap. Her philanthropy supported the populace's devotion to the Virgin Mary. She was a proud empress who did not tolerate opposition, while she devoted her life to the figure of compassion, grace and humility in the early Christian Church. During her life, she was a very popular Empress and after death in 453, the Church conferred sainthood upon her for her support of the Virgin Mary, the Theotokos. Without her influence and support it is entirely possible that there would have been a very different outcome of the two church councils that set the essence of the Western Church's doctrine on the nature of Christ and, therefore, the stature of his mother.

\section{Empress Wu Zetian}

Empress Wu Zetian of the Tang Dynasty also used sacred figures of compassion to solidify her power and Empire, but her legacy is more mixed as it has not had the institutional support St. Pulcheria has had. 
Empress Wu Zetian, also known as Wu Zhao, was the only female Emperor in Chinese history. She came from a family that had practiced Buddhism for generations while Taoism was prevalent and Confucian ideals predominated. Although her precise birthdate and place are subject to considerable speculation, it is generally agreed that she was born around the same time as Princess Wen Cheng, who in 641, married the Tibetan King, Tsongsten Gampo, and who by bringing Buddhism to Tibet (along with her Nepalese co-wife, Brikhruti) is considered to an incarnation of the feminine Buddhist deity of Compassion, Tara. At the age of thirteen or fourteen, Wu Zetian moved into the imperial court of the Emperor Taizong that was home to Princess Wen Cheng, a niece of the ruler. While there are no publically known records of any interactions between the two young teenaged girls, they both changed the religious practices of their respective countries. Tibet became Buddhist, while in China the religion improved in status and flourished.

After Emperor Taizong died in 649, Wu Zetian became the favorite consort of his son, the new Emperor Gaozong. After bearing him a son, she was able to have his wife, the Empress Wang, deposed and take on that role in 655. Gaozong's court was full of intrigues, and he, similar to his earlier Byzantine counterpart, Theodosius II, was often manipulated by the party who was closest to him at the moment. Empress Wu was adept at navigating court politics and repeatedly managed to gain the Emperor's favor and ear. By 664 she managed to be placed in a position as co-regent; they reigned as "Two Sages"; not dissimilarly to the situation with Pulcheria and Theodosius II. Wu Zetian, however, was not royally born and had been a concubine of two emperors. She did not have the support of the Court, nor at first of the people. Additionally, she was confronted with the previously mentioned popular Confucian attitude toward women, one that said "a woman ruler is as unnatural as a hen crowing like a rooster at daybreak” (Rothschild, 2006, p. 134). Somehow she needed to publically demonstrate “T'ien Ming” or rule by Heavenly Mandate. In 666, she found her opportunity to do so. She convinced the Emperor to allow her to participate in a very traditional ceremony honoring the primordial deities, the Heavenly Immortal Jade Mother and her brother the Jade Emperor. According to Chinese legend, these deities had descended to earth on the Taoist sacred Mt. Tai and created all life. Earth was governed by the goddess, Nuwa, who made humans, while the heavens were ruled by her brother from the higher Jade Emperor Peak. After the deities were finished with their work they ascended back to heaven (Palmer, Ramsay, \& Kwok, 1995, pp. 9-10).

There was an ancient tradition that the Emperor would demonstrate heaven and earth's support for his reign by performing the Feng (heaven) shan (earth) sacrifices by climbing Mt. Tai. Normally, these rituals were reserved for the Emperor and Crown Prince or high-level male officials, but Empress Wu convinced the Emperor that as the earth was associated with yin and the female essence, she and her Court women should perform the lower, earthly sacrifice, while he should perform the higher heavenly one.

According to Rothschild:

Belying her desire to play a more prominent and active political role, she couched her argument for participation in the shan sacrifice-a sacrifice to earth held at a lesser peak on Mount Tai-in self-effacing terms consistent with the humility expected of a Confucian wife. Gaozong accepted her contention that as earth was affiliated with the female essence, the tradition of having high male officials present secondary offerings in the shan sacrifice was inappropriate. (Rothschild, 2006, p. 136)

Amazingly, they succeeded; it was the first time in centuries that the sacrifice had been successfully performed. Emperor Taizong had tried to climb the mountain three times, but had failed. Their accomplishment 
was popularly understood to be a divine testament to Empress Wu's worthiness. To solidify her divine mandate, in 674, she took on the title of "Heavenly Empress". The Emperor died in 683 and she smoothly maintained control of the Imperial reins as Dowager Queen and Regent for her seven year old son. By 690 she managed to clear her political path to become sole Emperor and called her reign the "Heavenly Bestowed". She maintained her position on the Imperial throne until shortly before her death in 705 in approximately her 80th year. In total she reigned for a half century and during this time the Tang Dynasty with Chang'an as its capital saw tremendous growth and prosperity. In order to accomplish what she wanted, she needed to create an identity with a divine being to solidify her position as regent and to quell dissent.

In mid 7th century China patriarchal Confucianism was predominant in the Court and Imperial system, while the people were mostly Taoists or Buddhists or some synthesis of the two. In Taoism there is one major female deity, the Great Mother of the West, but in Chinese Buddhism during the 7th century there were no female figures. According to Yu:

Buddhist doctrine had always interpreted being female as a consequence of bad karma. One of the most attractive promises of Pure Land Buddhism was that there would be no women in the Western Paradise. Even if a person failed to go to the Pure Land, the merit created in this life would guarantee that one would not be born as a woman in the next. Such beliefs and sentiments did not empower women or take women's religious needs seriously. Nor did they foster respect for feminine symbols of veneration of goddesses. Similarly, Neo-Confuciansim was a very male oriented, patriarchal, and hierarchical system of thought. It did not recognize the presence of goddesses, nor provide much support for the intellectual and spiritual strivings of real women. Although its stated program was universal sagehood, its real intended audience was educated men. It did not encourage or promote devotionalism. It did not appreciate religious enthusiasm and emotional fervor. Thus there was an imbalance and a deprivation. There was too much yang and not enough yin. (Yu, 2001, p. 20)

Even the figure of compassion, Avalokiteshvara, was male. In the Chinese concept, however, karuna - compassion, was a female attribute. This gender role discrepancy seems to shift during Empress Wu's reign. Recent excavations around Chang'an/Xi'an have uncovered terracotta figurines of women in men's clothing riding horses and evidence of a female prime minister, which leads archeologists to suggest that during Empress Wu's period women enjoyed more equal rights than they had prior to her reign or would have after. To demonstrate “T'ien Ming” and proclaim her position as protector of the people, her face was sculpted onto the largest of the Longmen Grotto Buddhas. The Longmen Grottos had been a sacred place for installing images of Buddhas and Bodhisattvas since the 4th century and Empress Wu is said to have authorized around 380 images in the Longmen Caves. One of the most famous temples, the Fengxian, has a seated Vairocana Buddha that has a feminine face, commonly considered modeled on the Empress herself. The over 52' statue is the largest at Longmen and was said to have cost the equivalent of a year's worth of cosmetics. This figure is the central Buddha of a five figured grouping in the cave, showing both the Buddha's preeminence and the merciful Empress. As Pulcheria had her image merge with the Virgin Mary above the altar in St. Sophia, Empress Wu had hers as a Buddha towering above, and central to, all other sacred images in a main pilgrimage site. There is also a statue at the Dunhuang Caves that shows this merging of gender and deity; it was commissioned by the Yin family in 693/4 in Empress Wu's honor. Ning Qiang describes the statue:

Instead of following the common practice of molding the Buddha in a male body covered by a monk's robe, this statue was shaped according to a woman's bodily form and clothing. The imposing breasts are exposed to clarify the sex of the Buddha. The womanly dress further ensures her female identity. These unique features of the Buddha image, not found in other Buddha images at the site, thus demonstrates the local support for Empress Wu and reveal the local responses to 
the political reforms that took place in the capital, specifically, to the establishment of the legitimacy of a female monarch. (Qiang, 2003, p. 30)

In addition to the female attributes that began to occur in the paintings and sculptures of the Buddhist deities during her reign, she is attributed with bridging the concept of Xi Wangmu, the Great Mother of the West, with Kuan Yin, as well as with popularizing the multi-armed and eleven-headed Kuan Yin/Avalokiteshvara that had been common in India and Nepal, but not in China. "An inscription preserved in the Shoso-in records that Empress Wu commissioned a thousand embroidered images of the Eleven-headed Guanyin in commemoration of Emperor Gaozong’s death” (Wong, 2007, p. 280).

Kuan Yin's (Guan Yin's) name came from Kumarajiva’s translation of the Lotus Sutra in the early 3rd century of the Common Era. Chapter 25 of that work is devoted to the Bodhisattva Avalokitesvara, and his name was translated as Kuan Shi Yin, the one who hears (or perceives) the cries (or lamentations) of the world. In the Mahayana Buddhist tradition bodhisattvas are those beings who have freed themselves from karmic pollutants and can be released from Samsara, the cycle of death and rebirth. They can be free from limiting and determining form. As Yu states, "Avalokitesvara is a cosmic figure, creator and savior of all beings and all worlds” (Yu, 2001, p. 4). Bodhisattvas deliberately choose to stay within the world of form to help all sentient beings free themselves from mental and emotional obfuscations that prevent them from realizing the Oneness of All. This is the perfect figure for merging the female attribute of "karuna" with a Buddhist deity and one that Empress Wu could model herself on for her public appearance with the populace. That she showed a wrathful side to the Court is an entirely different affair.

Karuna implies showing mercy and, according to Alice Getty in The Gods of Northern Buddhism, this quality "seems to have appealed to the Chinese as feminine rather than masculine for a goddess of Mercy, believed to be the feminine manifestation of Avalokitesvara, made her appearance and drew worshippers" (Yu, 2001, p. 6). Her role as "Giver of Children" also seems to have contributed to the feminization of the bodhisattva. Prior to Kuan Yin there were no Chinese models for a deity who was concerned with universal salvation for all regardless of status and merit, and while there were goddesses, they never combined salvation in the world beyond with assistance in this plane (Yu, 2001, p. 5). The most common female deities were the indigenous Nuwa, who holds up the Wall of Heaven and created the human race, and the Taoist Xi Wangmu, the Queen Mother of the West. These figures did not have the same impact as a central female deity, however, as they were less important that the male figures in their respective pantheons, but there were models from other cultures on which the combined nature of the feminine Kuan Yin was based, most specifically the Tibetan Tara, of whom Wu's childhood “classmate”, Wen Cheng, was said to be an incarnation.

According to legend, Avalokitesvara had reached enlightenment and was free from all delusions when he turned to see and hear the cries of the world; he then vowed not to leave until all sentient beings were released from their suffering. With this act he became the Bodhisattva of Compassion. He was unable to reach out to the world with his normal form, so he grew (or Amitabha Buddha gave him, the accounts differ according to tradition), eleven heads with which to see in all directions and a thousand arms to stretch out to all sentient beings in the six realms of Buddhist existence. In some paintings, he also has eyes on each of the hands, like the all-seeing Argos from the earlier Greek tradition. Like Argos, he is a protector, but not of property like the Greek, but of the Dharma, the belief system, and a model of caring and compassion for people to emulate as well as worship. His compassion is greater than the term in English normally implies, as karuna, the original 
Sanskrit term, goes beyond caring for another and is closer to "being one with". Karuna is a state of being where there is no separation; what one feels the other feels, the one and the other are the same. It is this form of compassion that Avalokitesvara represents, and this is the original concept for Kuan Yin.

Images of Avalokitesvara first appeared in the Gandhara (modern day Pakistan/Afghanistan) and Mathura (North India) regions by the second century CE. Depictions of the eleven-headed form of the bodhisattva occurred later, in about the late fifth to early sixth centuries in the Kanheri Caves. Both would have been readily visible to the early Chinese monks who travelled to India to obtain the official versions of Sanskrit Buddhist texts and bring them back for translation. FaHsien (ca. 337-424) would have seen the earliest paintings of Avalokitesvara on his journey to India and Xuanzang (ca. 600-664) would have had access to images of the multi-armed form of the bodhisattva. Additionally, the Silk Route trade, which flourished during Empress Wu's tenure, would have brought these images to the capital city.

Early Chinese images of Avalokitesvara/Kuan Yin show a refined composed male personage, sometimes sporting a mustache, in flowing robes. This Kuan Yin is, in his imagery, related to the balanced and harmonious styles of Taoist art. The vibrant un-human Indian and Himalayan depictions of Avalokitesvara with eleven heads and a thousand arms are singularly missing from the early male Chinese portrayals of Kuan Yin, though at this early period, they are supposed to be one in the same figure. It is only with the reign of Empress Wu Zetian that the eleven-headed bodhisattva's image is popularized, as well as the emergence of the deity's female attributes. By the Sung Dynasty in the 10th century the transformation from male to female is complete, with the only remaining male images of the deity reserved solely for inner sanctuaries in temples.

Throughout her reign as Empress from 655-705 Wu was instrumental in promoting her political power not only through visual imagery merging her image with a Buddha, but also through sacred legends and Buddhist texts; as tribute she made Buddhism the state religion and commissioned hundreds of Buddhist images and structures. She used not only the earlier mentioned Fengshan ceremony to solidify her role, but also the Lotus Sutra and in 690 the Dayun Jing (Grand Cloud Sutra), which describes a prophecy of a reincarnation of Maitreya, the future Buddha, as a female deity and ruler of the world.

The Dayun Jing describes the world under the female rule: "Harvests will be bountiful, joy without limit. The people will flourish, free of desolation and illness, of worry, fear and disaster [...] At that time all her subjects will give their allegiance to this woman as the successor to the imperial throne. Once she has taken the Right Way, the world will be awed into submission.” (Qiang, 2003, p. 31)

In order to promote the distribution of this text, she commissioned the building of pagodas across the Empire to house copies of the Sutra. As tribute to the Lotus Sutra, she built the multi-faced pillar of the Tower of Seven Treasures in Guangzhaisi Temple in Chang'an, as it is a central image to the text. She also used the Treasury Rain Sutra found in Dunhuang Cave 321. The murals and texts found dedicated to her in Dunhuang indicate the popularity she had with the people and how her promotion of Buddhism in general, and Kuan Yin in particular, flourished during her reign. While Empress Wu did not specifically change the gender of the bodhisattva, her influence and feminizing of Buddha images likely played a part in the transformation that took centuries to complete. Clearly she did want to be seen as ruling through divine right and that divinity was Buddhist and there needed to be a feminine deity with whom she could be identified. She demonstrated the attributes of compassion of her chosen deity in providing for the common people while she ruled the Court as a wrathful god. 


\section{Common Threads}

Chang'an, like Constantinople, became "The” major metropolis during their empress' reigns. Where Pulcheria built churches and hospices, Wu built the Daming Palace to showcase the power and majesty of the Tang Dynasty, pagodas for the people to worship in and granaries to feed them. In keeping with the Kuan Yin spirit of compassion for her subjects, the Empress established local granaries, not unlike Pulcheria's "Steps", that were insulated so that they could store rice for up to ten years, providing the populace with food in times of drought. So far upwards of 280 such granaries have been found in the former capital with archeologists suspecting there could be upwards of 500. During both women's reign, life and status for women in their capitals noticeable improved. Both tried to create meritocracies, with Empress Wu starting the Imperial Exams, which were intended to identify the best qualified candidates for governmental offices rather than the previous system of heredity and nepotism. Under their leadership their empires flourished through trade as well as through conquest. They each were instrumental in strategic battles that increased the size of their territories. On the religious side, Pulcheria brought holy relics and jewels to Constantinople, while Wu commissioned, or had dedicated to her, Buddhist statues and paintings across her vast nation. Both were influential in the development of sacred texts for their respective faiths. Empress Pulcheria's influence is apparent in the text that developed from the two Councils, and Empress Wu's with the promotion of the Lotus Sutra as well as the "finding" of the Dayun Jing Sutra and the Treasury Rain Sutra. Empress Wu also influenced the gender change of the leading now-female deity in Chinese Buddhism, Kuan Yin.

A brief list of some of their similarities includes:

Empress Pulcheria and Empress Wu were the only truly long-standing ruling empresses for their respective cultures. They started out as co-rulers, but the main power was in their hands, and they continued to rule after the death of the emperor. Empress Wu was called "Emperor" when she was sole ruler from 690/691 to her abdication in 705 .

Both lived part of their lives as nuns within their respective traditions. Pulcheria was a nun by dedication, Wu by necessity as all imperial concubines that had not born a child were sent to a convent after their Emperor died.

They were steeped in religious traditions that were not mainstream, and both spent their careers and lives promoting their faiths against what they believed to be heretical views.

They both chose deities of compassion to associate with and to publically model themselves on; in Pulcheria's case spiritually and physically, in Wu Zetian's materially.

They both used the deities to rally their soldiers in actual battles against enemies of their empires. Pulcheria and Theodosius II fought against the Persians and the victory was attributed to Pulcheria's virginity as a sign of her association with the Virgin Mary, and Wu Zetian subdued a rebellious vassal state, Khitan, with the help of Buddhist and Taoist ceremonies and a specific public ceremony dedicated to Kuan Yin.

They both commissioned sacred images, artifacts, and worship sites to glorify their chosen divine figure, thereby promoting their personal as well as spiritual images.

They both established cults for their respective deities through the use of propaganda, and the creation of sacred texts and images.

They both had philanthropic systems in place to take care of the common people, including the distribution of food and health care resources. 
The difference in their legacies is that the Roman Catholic Church made Pulcheria a saint for her efforts to promote the Virgin Mary, while Empress Wu had no such support. Primarily her ruthless acts within the Court and about those who opposed her will were transmitted to the future. It is only within the past few years, that archeologists and scholars are discovering another side to her story and to her reign and influence on bringing a feminine facet to Chinese Buddhism. In 2015 CCTV, the Chinese central television system, had a 96 part series on her trying to show a more human side of her story than earlier depictions had portrayed. Empress Wu is buried with her husband and her memorial stele remains blank. Her legacy is still unwritten. There is much more to be discovered about her influence on popularizing devotion to Kuan Yin and especially about her early foundational years in Taizong's Court with Princess Wen Cheng.

\section{Conclusion}

The use of imperial power was instrumental in the establishment of the on-going devotion to sacred feminine figures of compassion in the Roman Catholic and Chinese Buddhist traditions. Empress Pulcheria and Empress Wu Zetian used their power to influence and change not only the political atmosphere they found themselves in, but also promoted the idea of a compassionate female "deity" that was an intercessor with heaven on behalf of the people. Both used this model in the public perception of themselves, while both were characterized as cut-throat to those who challenged them. Pulcheria has received better press from subsequent generations as she has been canonized by the Catholic Church. Empress Wu Zetian did not have such luck as the Confucian model of gender roles came back into force after her death. The records we have of her are all from men who were not necessarily in favor of a female ruler. Nonetheless, the development of devotion to Kuan Yin, can be attributed to her reign, as can the decisions about Mary at the Ecumenical Councils of Ephesus in 431 and Chalcedon in 451 to Empress Pulcheria. These two empresses, the only female rulers from their long-standing empires, Byzantium and the Tang Dynasty, were instrumental in the development of devotion to sacred feminine compassionate figures, while at the same time promoting the well-being of the people of their empires.

\section{References}

Atanassova, A. (2010). Orthodox women's defense of the Theotokos: The case of Empress Pulcheria and the Council of Ephesus. Retrieved from http://hdl.handle.net/10022/AC:P:11154

Baring, A., \& Cashford, J. (1993). The myth of the goddess: Evolution of an image. London: Arkana Penguin Group.

Constas, N. P. (1995). Weaving the body of God: Proclus of Constantinople, the Theotokos, and the loom of the flesh. Journal of Early Christian Studies, 3(2), 172. Retrieved from http://muse.Jhu.edu/journals/earl/summary/v003/3.2constas.html

Ebrey, Patricia. (2011). Cave Temples: Longmen. Retrieved from http://depts.washington.edu/chinaciv/bud/5temcave.htm

Getty, A. (1988). The Gods of Northern Buddhism: Their history and iconography. London: Dover Publications.

Hahn, S. (2001). Hail, Holy Queen: The Mother of God in the Word of God. NY: Doubleday.

Justinian. (2010). The Nobleborn Empress Pulcheria. Codex Justinianus. Retrieved from

Codexjustinianus.blogspot.com/2010/09/nobleborn-empress-pulcheria.html

Karcher, S. (2010). The Kuan Yin oracle. London: Piatkus.

Palmer, M., Ramsay, J., \& Kwok, M. H. (1995). Kuan Yin. Myths and prophecies of the Chinese goddess of compassion. San Francisco: Thorsons.

Pelikan, J. (1996). Mary through the centuries: Her place in the history of culture. New Haven: Yale University Press.

Qiang, N. (2003). Gender politics in medieval Chinese Buddhist art; images of Empress Wu at Longmen and Dunhuang. Oriental Art, 2, 31.

Roman Catholic Mariology. (2011). Pope Pius XII Mariology. Newnan, GA: Hephaestus Books. 
Rothschild, N. H. (2006). An inquiry into reign era changes under Wu Zhao, China’s only female emperor. Early Medieval China, 12, 136.

Taranatha, J. N., \& Templeman, D. (Eds. \& Trans.). (2007). The origins of Tara Tantra. Dharamsala: Library of Tibetan Works and Archives.

Teetgen, A. B. (2010). The life and times of the Empress Pulcheria A.D. 399 A.D. - A.D. 452. Charleston, SC: Nabu Press. Retrieved from http://en.calameo.com/books/000477687ed6b9f808e1f

Wong, D. (2007). Guanyin images in medieval China. Guanyin and Modern Society: Proceedings of the Fifth Chung-Hwa International Conference on Buddhism. Taipei: Dharma Drum Publ.

Yu, C. F. (2001). Kuan Yin: The Chinese transformation of Avalokiteshvara. NY: Columbia University Press. 